\title{
Synthesis and Structure of 1-Substituted Semithioglycolurils
}

\author{
Vladimir V. Baranov*a (D) \\ Anton A. Galochkin ${ }^{\mathrm{a}, \mathrm{b}}$ (D) \\ Yulia V. Nelyubinac \\ Angelina N. Kravchenko a,d \\ Nina N. Makhova ${ }^{a}$ \\ ${ }^{a}$ N. D. Zelinsky Institute of Organic Chemistry, Russian Academy of \\ Sciences, 47 Leninsky Prosp., Moscow 119991, Russian Federation \\ ase1313@mail.ru \\ ${ }^{b}$ D. I. Mendeleev University of Chemical Technology of Russia, 9 \\ Miusskaya Sq., Moscow 125047, Russian Federation \\ c A. N. Nesmeyanov Institute of Organoelement Compounds, Russian \\ Academy of Sciences, 28 Vavilova St., Moscow 119991. \\ Russian Federation \\ d Plekhanov Russian University of Economics, Stremyanny Lane 36, \\ Moscow 117997, Russian Federation
}

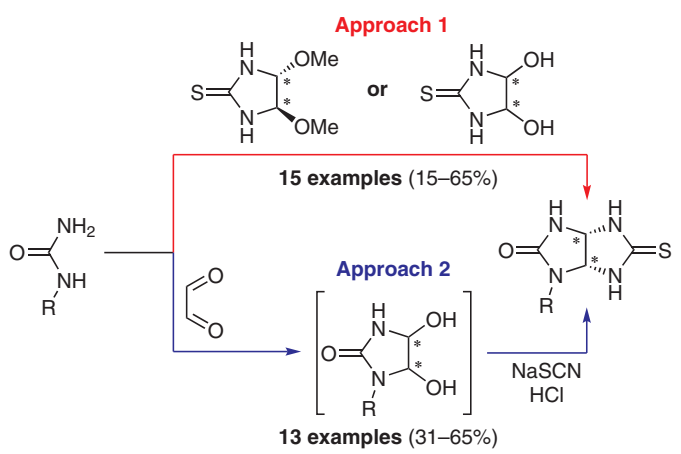

Although a wide range of trisubstituted semithioglycolurils I and II have been reported, they are still actively investigated, as some of them have antifungal and cytotoxic activities. ${ }^{12,13}$ Other compounds III-IX are represented by several examples and used as scaffolds in the synthesis of semithiobambusurils (III and VII), ${ }^{11,27}$ in Claisen condensation matrices (IV) ${ }^{10}$ and in the synthesis of tri-, tetra-, and polycyclic systems $(\mathbf{V})^{28-31}$ and iminoglycolurils $(\mathbf{V}, \mathbf{V I I}$, VIII). ${ }^{6}$ Methods for the preparation of a small number of compounds III-IX reported in the literature are underdeveloped. The focus of this article is on a methodology for the synthesis of 1-substituted semithioglycolurils.

Semithioglycolurils have so far been represented by only three examples (Scheme 1).6,14,25 Compounds 1a,b were obtained by the reaction of 1-alkylureas $\mathbf{2 a}$, $\mathbf{b}$ with 4,5-dimethoxyimidazolidine-2-thione (DMIT; 3) or 4,5-dihydroxyimidazolidine-2-thione (DHIT; 4) (approach 1).6,25 Semithioglycoluril 1c was prepared by the condensation of 1-cyclohexyl-4,5-dihydroxyimidazolidin-2-one (5a) with KSCN and hydrochloric acid (approach 2). ${ }^{14}$ Here, these approaches were studied in detail, and two methods for the synthesis of 1-substituted semithioglycolurils were developed.
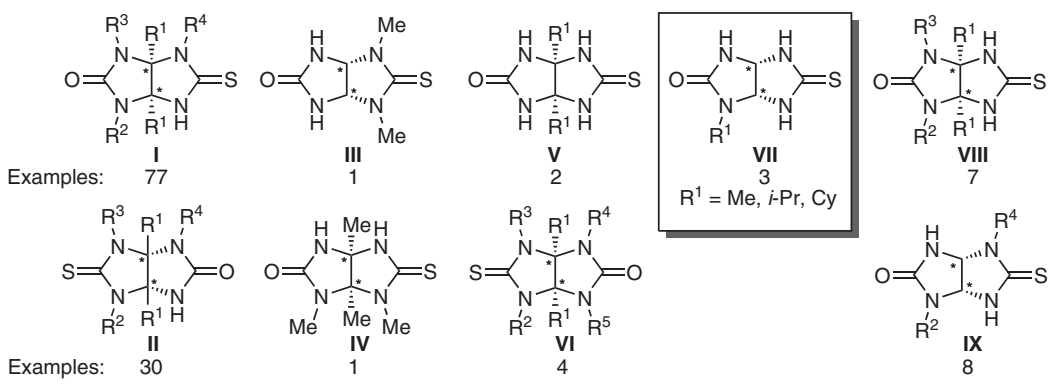

Figure 1 Previously reported semithioglycolurils 


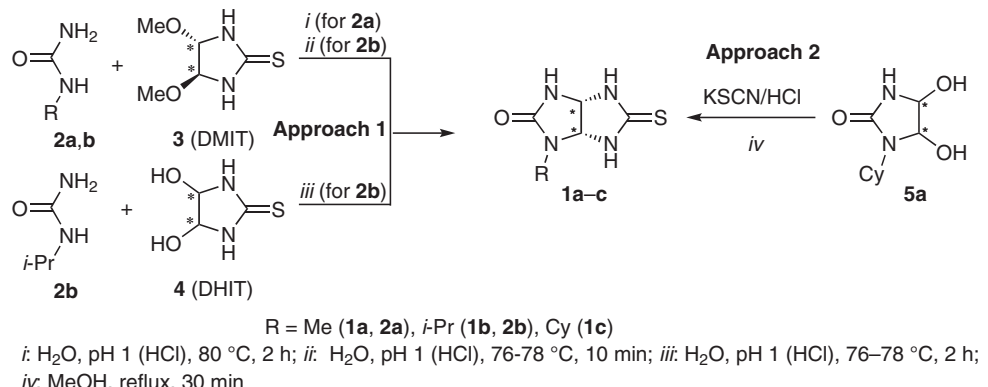

Scheme 1 Two approaches for the synthesis of 1-alkyl-substituted semithioglycolurils 1a-c

To develop approach 1 , we started with the reactions of DMIT (3) and DHIT (4) with ethylurea (2c) in water by varying the amount of hydrochloric acid $(\mathrm{pH} 1)$ and time used for heating the reaction mixture (10 $\mathrm{min}, 30 \mathrm{~min}, 1 \mathrm{~h}$, and 2 h) at $76-80{ }^{\circ} \mathrm{C}$ (Table 1 ). By ${ }^{1} \mathrm{H}$ NMR monitoring of dried reaction mixture aliquots, the dependence of the conversion of ethylurea (2c) into thioglycoluril 1d on the reaction conditions was analyzed. The conversion rate was estimated by analyzing the proton signals of the Me groups of urea $2 \mathrm{c}(\mathrm{t}$, $\delta=0.96)$ and thioglycoluril $\mathbf{1 d}(\mathrm{t}, \delta=1.02)$ and the $\mathrm{CH}-\mathrm{CH}$ group of thioglycoluril $\mathbf{1 d}(\mathrm{d}, \delta=5.46)$. It was established that the conversion of $\mathbf{2 c}$ to $\mathbf{1 d}$ is $33 \%$ and $37 \%$ when the reaction of urea 2c with DMIT (3) is carried out with hydrochloric acid $(0.027 \mathrm{~mL})$ for 30 minutes and 1 hour, respectively (Table 1 , entries 1,2 ).

When the volume of hydrochloric acid $(0.08 \mathrm{~mL})$ was increased, the conversion of $\mathbf{2 c}$ into $\mathbf{1 d}$ increased to 41 and $64 \%$, for 10 minutes and 1 hour of reaction time, respectively (Table 1, entries 3 and 5), and remained constant even after 2 hours of reaction (entry 6). Similar results were observed when we used DHIT (4); however, the reaction rate of forming semithioglycoluril 1d increased. After 10 minutes, the conversion of $\mathbf{2 c}$ into $\mathbf{1 d}$ was $52 \%$ (entry 7 ), and increased to $64 \%$ after 30 minutes (entry 8 ). Therefore, it is more efficient to use DHIT (4) rather than DMIT (3), with a reaction time of 30 minutes. Apart from that, we noticed that DHIT (4) is partially consumed in a competing reaction to produce the earlier reported 2-thioxoimidazolidin-4-one (thiohydantoin) ${ }^{32}$ (the most characteristic signal of $\mathrm{CH}_{2}$ protons: s, $\delta=4.06)$; we also detected ethylurea $(\mathbf{2 c})$ in the reaction mixture.

For a more complete transformation of ethylurea (2c) into semithioglycoluril 1d, we used a larger amount of DHIT (4) (1.2 and 1.5 equiv; Table 1, entries 12 and 11, respectively). ${ }^{1} \mathrm{H}$ NMR monitoring of this reaction showed that the conversion of $\mathbf{2 c}$ into $1 \mathbf{d}$ was $65 \%$ with DHIT (1.5 equiv) after 30 minutes of heating, but DHIT was still present in the resulting product (entry 11 ). The use of DHIT (4; 1.2 equiv) in this reaction led to an increase of the conversion of ethylurea (2c) to thioglycoluril 1d up to $71 \%$ after 30 minutes (entry 12). The yield of thioglycoluril 1d was $52 \%$ after its purification (Table 2 , approach 1 , entry 3 ). Thus, the best yield of thioglycoluril 1d was achieved in the reaction of DHIT (4; $2.5 \mathrm{mmol}, 1$ equiv) with ethylurea (2c) in a $\mathbf{4} / \mathbf{2 c}$ ratio of $1.2: 1$ in water with $35 \%$ hydrochloric acid $(0.08 \mathrm{~mL})$ at $76-80^{\circ} \mathrm{C}$ for $30 \mathrm{~min}$ (Table 1 , entry 12 ).

The target glycolurils 1a-m,o,p were synthesized in 15$65 \%$ yield by using the optimized conditions of condensation of DHIT (4) with 1-substituted ureas 2a-m,o,p (Table 2, approach 1 , entries $1-13,15,16)$. In total, 15 compounds were synthesized by approach 1 .

Table 1 Screening of Conditions for the Synthesis of Thioglycoluril 1d (Approach 1)

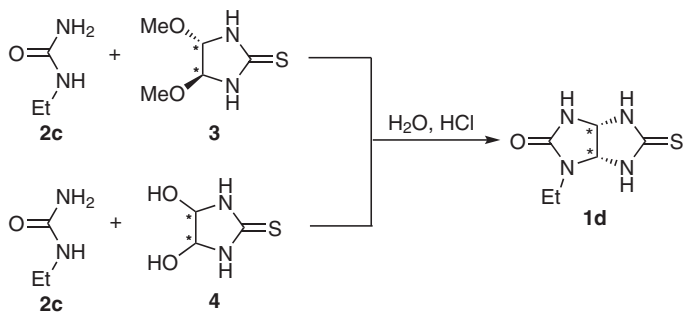

\begin{tabular}{|c|c|c|c|c|}
\hline Entry & $\begin{array}{l}\text { Reagents } \\
\text { (ratio) }\end{array}$ & $\begin{array}{l}\mathrm{Aq} \mathrm{HCl} \\
(35 \%)(\mathrm{mL})\end{array}$ & Time & $\begin{array}{l}\text { Conversion } \\
(\%)^{b}\end{array}$ \\
\hline 1 & 2c, $3(1: 1)$ & 0.027 & $30 \mathrm{~min}$ & 33 \\
\hline 2 & 2c, $3(1: 1)$ & 0.027 & $1 \mathrm{~h}$ & 37 \\
\hline 3 & $2 c, 3(1: 1)$ & 0.08 & $10 \mathrm{~min}$ & 41 \\
\hline 4 & 2c, $3(1: 1)$ & 0.08 & $30 \mathrm{~min}$ & 59 \\
\hline 5 & 2c, $3(1: 1)$ & 0.08 & $1 \mathrm{~h}$ & 64 \\
\hline 6 & 2c, 3 (1:1) & 0.08 & $2 \mathrm{~h}$ & 64 \\
\hline 7 & 2c, $4(1: 1)$ & 0.08 & $10 \mathrm{~min}$ & 52 \\
\hline 8 & $2 c, 4(1: 1)$ & 0.08 & $30 \mathrm{~min}$ & 64 \\
\hline 9 & 2c, $4(1: 1)$ & 0.08 & $1 \mathrm{~h}$ & 65 \\
\hline 10 & 2c, $4(1: 1)$ & 0.08 & $2 \mathrm{~h}$ & 65 \\
\hline 11 & 2c, $4(1: 1.5)$ & 0.08 & $30 \mathrm{~min}$ & 65 \\
\hline 12 & 2c, $\mathbf{4}(1: 1.2)$ & 0.08 & $30 \mathrm{~min}$ & $71^{c}$ \\
\hline
\end{tabular}

a Reaction conditions: $2 \mathrm{c}$ ( $2.5 \mathrm{mmol}, 1$ equiv), 3 or $\mathbf{4}, \mathrm{H}_{2} \mathrm{O}(10 \mathrm{~mL})$, aq $\mathrm{HCl}$ (35\%), $76-80^{\circ} \mathrm{C}$.

${ }^{b}$ Conversion of $\mathbf{2} \mathbf{c}$ into $\mathbf{1 d}$ according to ${ }^{1} \mathrm{H}$ NMR spectroscopy.

c Reaction conditions: $2 \mathrm{c}(0.22 \mathrm{~g}, 2.5 \mathrm{mmol}), 4(0.40 \mathrm{~g}, 3.0 \mathrm{mmol}), \mathrm{H}_{2} \mathrm{O}$ $(10 \mathrm{~mL})$, aq $\mathrm{HCl}(35 \%, 0.08 \mathrm{~mL}), 76-80^{\circ} \mathrm{C}, 30 \mathrm{~min}$. 
Table 2 Comparison of Two Approaches to the Synthesis of Semithioglycolurils 1a-p

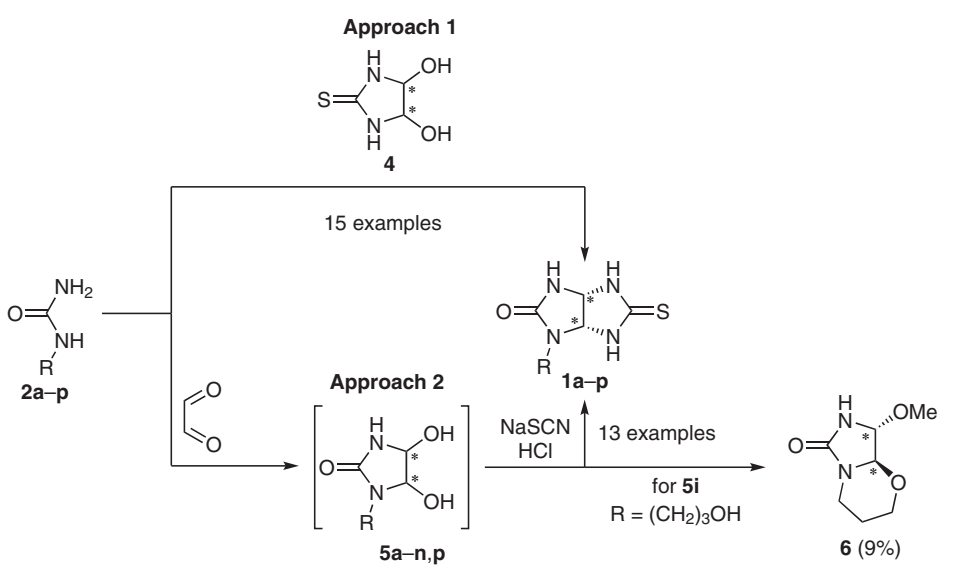

\begin{tabular}{|c|c|c|c|c|c|c|}
\hline Entry & $\mathrm{R}$ & Urea & $\mathrm{DHI}$ & Product & Yield (\%) of $\mathbf{1}$ by approach $1^{\text {a }}$ & Yield (\%) of $\mathbf{1}$ by approach $2^{\mathrm{b}, \mathrm{c}}$ \\
\hline 1 & $\mathrm{Me}$ & $2 a$ & $5 b$ & $1 a$ & 51 & $31^{b}$ \\
\hline 2 & $i-\mathrm{Pr}$ & $2 b$ & $5 c$ & $1 b$ & 50 & $52^{b}$ \\
\hline 3 & Et & $2 c$ & $5 d$ & 1d & 52 & $58^{\mathrm{b}}$ \\
\hline 4 & $\operatorname{Pr}$ & $2 d$ & $5 e$ & $1 e$ & 20 & $55^{b}$ \\
\hline 5 & $t-B u$ & $2 e$ & $5 f$ & $1 f$ & 61 & $50^{\mathrm{b}}$ \\
\hline 6 & Cy & $2 f$ & $5 a$ & 1c & 65 & $9^{d}$ \\
\hline 7 & $\mathrm{CH}_{2} \mathrm{C}-\mathrm{C}_{3} \mathrm{H}_{5}$ & $2 g$ & $5 g$ & $1 \mathrm{~g}$ & 45 & $53^{b}$ \\
\hline 8 & $\left(\mathrm{CH}_{2}\right)_{2} \mathrm{OH}$ & $2 \mathrm{~h}$ & $5 \mathrm{~h}$ & $1 \mathrm{~h}$ & 26 & $54^{\mathrm{b}}$ \\
\hline 9 & $\left(\mathrm{CH}_{2}\right)_{3} \mathrm{OH}$ & $2 \mathbf{i}$ & $5 i$ & $1 \mathbf{i}$ & 15 & $0(\mathbf{1 i})^{b}, 9(\mathbf{6})^{b}$ \\
\hline 10 & $\mathrm{Me}_{2} \mathrm{CCH}_{2} \mathrm{OH}$ & $2 \mathbf{j}$ & $5 \mathbf{j}$ & $1 \mathrm{j}$ & 41 & $45^{b}$ \\
\hline 11 & All & $2 k$ & $5 k$ & $1 \mathrm{k}$ & 40 & $62^{c}$ \\
\hline 12 & $\mathrm{Bn}$ & 21 & $5 I$ & 11 & 45 & $63^{c}$ \\
\hline 13 & PMB & $2 m$ & $5 m$ & $1 \mathrm{~m}$ & 46 & $65^{c}$ \\
\hline 14 & $\left(\mathrm{CH}_{2}\right)_{2} \mathrm{Ph}$ & $2 n$ & $5 n$ & 1n & - & $61^{c}$ \\
\hline 15 & $\mathrm{Ph}$ & 20 & - & 10 & 34 & - \\
\hline 16 & $\left(\mathrm{CH}_{2}\right)_{3} \mathrm{CO}_{2} \mathrm{H}$ & $2 p$ & $5 p$ & $1 p$ & 36 & - \\
\hline
\end{tabular}

a Reaction conditions: $2(2.5 \mathrm{mmol}), 4(0.40 \mathrm{~g}, 3.0 \mathrm{mmol}), \mathrm{H}_{2} \mathrm{O}(10 \mathrm{~mL})$, aq HCl $(35 \%, 0.08 \mathrm{~mL}), 76-80{ }^{\circ} \mathrm{C}, 30 \mathrm{~min}$.

${ }^{b}$ Reaction conditions: 1.2 (20 mmol), glyoxal hydrate trimer (1.61 g, $\left.7.7 \mathrm{mmol}\right), \mathrm{H}_{2} \mathrm{O}(10 \mathrm{~mL}), \mathrm{NaOH}($ to $\mathrm{pH} 10), 50-55^{\circ} \mathrm{C}, 3 \mathrm{~h} .2 . \mathrm{MeOH}(20 \mathrm{~mL}), \mathrm{NaSCN}(3.65$ g, $45 \mathrm{mmol})$, aq $\mathrm{HCl}(35 \%, 4.4 \mathrm{~mL})$; NaCl precipitate removed by filtration; filtrate refluxed, $30 \mathrm{~min}$.

c Reaction conditions: 1.2 (20 mmol), glyoxal hydrate trimer (1.61 g, $7.7 \mathrm{mmol}), i-\mathrm{PrOH}(10 \mathrm{~mL})$, reflux, $5 \mathrm{~h} .2 . \mathrm{MeOH}(20 \mathrm{~mL}), \mathrm{NaSCN}(3.65 \mathrm{~g}, 45 \mathrm{mmol})$, aq HCl $(35 \%, 4.4 \mathrm{~mL})$; $\mathrm{NaCl}$ precipitate removed by filtration; filtrate refluxed, $30 \mathrm{~min}$.

d Total yield of 1c [5a: $12 \%$ (stage 1), ${ }^{33}$ 1c: $74 \%$ (stage 2$)^{14}$ ].

As 1-cyclohexyl-DHI 5a had been prepared before, ${ }^{32}$ approach 2 made use of the condensation of DHI 5 with NaSCN and hydrochloric acid, so that 1-substituted DHI 5b-o had to be prepared (Table 2). To do so, a model reaction of ethylurea (2c) and glyoxal was examined under the same conditions that were used for the synthesis of 1,3-dimethyl-DHI, with $\mathrm{H}_{2} \mathrm{O}$ as the solvent, at $\mathrm{pH} 10$ and $50-55^{\circ} \mathrm{C} .{ }^{34}$ The next goal was to determine the reaction time needed for ethylurea $\mathbf{2 c}$ to completely transform into DHI $\mathbf{5 d}$. We used ${ }^{1} \mathrm{H}$ NMR monitoring of dried reaction mixture aliquots (after 5 min, 1 h, $2 \mathrm{~h}$ and $3 \mathrm{~h}$; Figure 2). It was established that the conversion of urea $\mathbf{2 c}$ into DHI $\mathbf{5 d}$ was complete after 3 hours. After this time, the signals of the protons of urea $\mathbf{2 c}$ disappeared, while new signals of the DHI protons appeared in the ${ }^{1} \mathrm{H}$ NMR spectrum (Figure $2 \mathrm{~d}$ ). As no side products were detected (Figure $2 \mathrm{~d}$ ), we used a reaction mixture in the reaction with NaSCN and hydrochloric acid, without isolation of DHI $\mathbf{5 d}$ (as well as of DHI $\mathbf{5 b}, \mathbf{c}, \mathbf{e}-\mathbf{h}, \mathbf{j}$ ). Target compound 1d was obtained in 58\% yield (Table 2, approach 2, entry 3 ). Condensation of ureas $\mathbf{2 a - e , g , h , j}$ with glyoxal was carried out in water for 3 hours at $50-55^{\circ} \mathrm{C}$. As a result, we synthesized a series of thioglycolurils $\mathbf{1 a}, \mathbf{b}, \mathbf{d}, \mathbf{e , f}, \mathbf{g}, \mathbf{h}, \mathbf{j}$ in 31-58\% yield (Table 2, approach 2, entries $1-5,7,8,10$ ). It turned out that DHI $5 \mathbf{i}, \mathbf{p}$ do not produce 


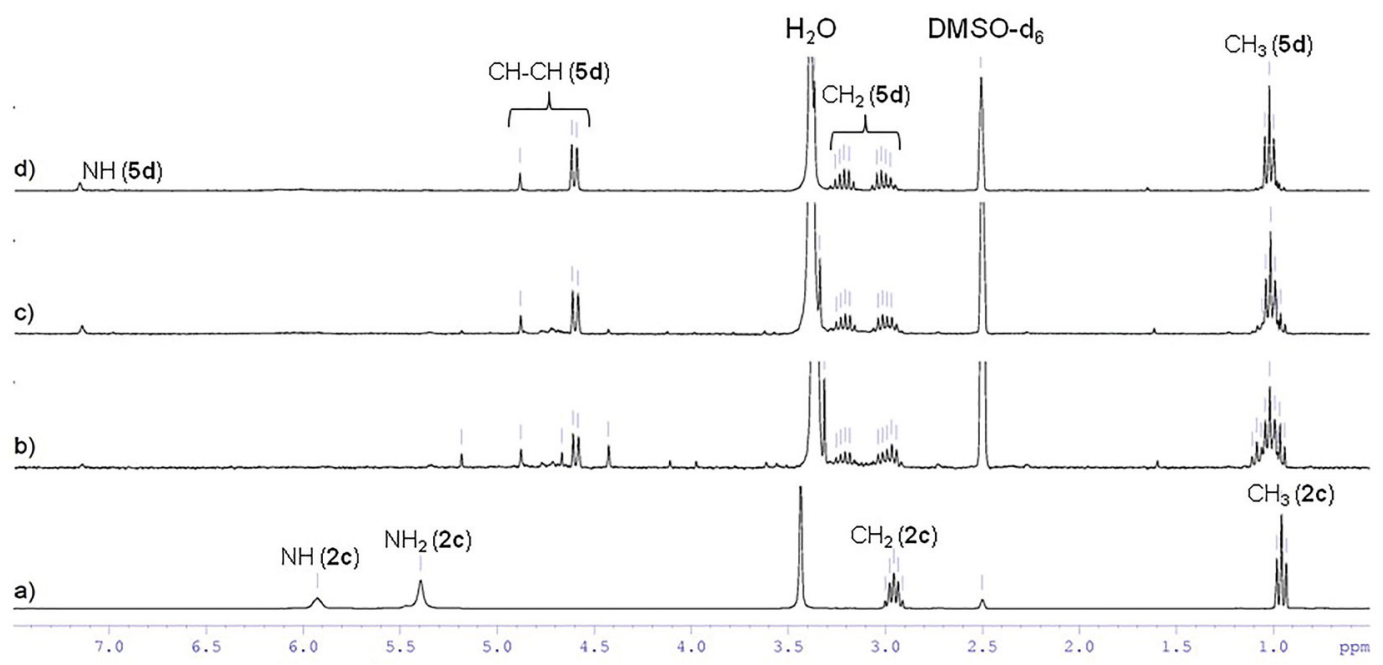

Figure 2 Conversion of ethylurea (2c) into DHI $\mathbf{5 d}$, followed by ${ }^{1} \mathrm{H}$ NMR spectra (DMSO- $d_{6}$ ) of ethylurea (2c) (a) and the reaction mixture after 10 min (b), $2 \mathrm{~h}(\mathrm{c})$, and $3 \mathrm{~h}$ (d).

semithioglycolurils 1i,p (entries 9, 16). Imidazooxazine 6 was isolated in $9 \%$ yield instead of product $\mathbf{1 i}$ (entry 9 ), although signals of the protons of compound $1 \mathbf{i}$ were found in a ${ }^{1} \mathrm{H}$ NMR spectrum of the reaction mixture.

As ureas 2k-o do not dissolve in $\mathrm{H}_{2} \mathrm{O}$, it was necessary to develop another synthetic approach to DHI 5k-n. As a model reaction, we chose the reaction between 1-benzylurea $\mathbf{2 l}$ and glyoxal. The reaction was carried out in $\mathrm{MeOH}$ or $i-\mathrm{PrOH}$ at $\mathrm{pH} 7$ or 10 (Table 3). Reaction progress was again monitored by ${ }^{1} \mathrm{H}$ NMR spectroscopy. The best results were achieved in refluxing $i-\mathrm{PrOH}$ at $\mathrm{pH} 7$. Under these conditions, a 100\% conversion of urea $\mathbf{2 l}$ to DHI $\mathbf{5 1}$ (Table 3, entry 9; see also Supporting Information, SI, Figure S1) was observed, so there was no need to isolate DHI $\mathbf{5 l}$ for the following reaction with NaSCN and hydrochloric acid. Target thioglycoluril 11 was synthesized in $63 \%$ yield (Table 2, approach 2 , entry 12 ). The same methodology was applied for the synthesis of DHI $\mathbf{5 k}, \mathbf{m}, \mathbf{n}$ and semithioglycolurils $\mathbf{1 k}, \mathbf{m}, \mathbf{n}$ (yields 61-65\%) (entries 11, 13, 14). Urea 20 did not produce DHI 5o, and it was separated from the reaction mixture without any change.

Semithioglycolurils $\mathbf{1 i}, \mathbf{o}, \mathbf{p}$ can be synthesized only by approach 1, while compound $\mathbf{2 n}$ can only be obtained by approach 2 (Table 2). The yields of semithioglycolurils 1e,g,h,k-m from approach 2 are 8-35\% higher. For compounds $\mathbf{1 a}, \mathbf{c}, \mathbf{f}$, the approach 1 resulted in higher yields (by $11-56 \%$ ). The yields of compounds $\mathbf{1} \mathbf{b}, \mathbf{d}, \mathbf{j}$ were almost the same $(50-52 \%, 52-58 \%, 41-45 \%$, respectively), so that they can be synthesized by either of the proposed two methods.

The formation of the target semithioglycolurils 1 was unambiguously confirmed by X-ray diffraction data collected for 1a,b,d,j (SI, Figures S2 and S3), which revealed two conglomerates ( $\mathbf{1 a}$ and $\mathbf{1} \mathbf{j}$ crystallized in the $P 2_{1} 2_{1} 2_{1}$ space group) and two racemates (1) and $\mathbf{1 d}$ crystallized in the
$\mathrm{C2} / \mathrm{c}$ space group) among these semithioglycololurils. Of the four, only $\mathbf{1} \mathbf{j}$ has a substituent at one of its nitrogen atoms, the $\mathrm{C}(\mathrm{Me})_{2} \mathrm{CH}_{2} \mathrm{OH}$ group, which is able to form a hydrogen bond; however, its resulting crystal structure is isostructural with the one for 1a with the methyl group in the same position of the urea. In both cases, the formation of a conglomerate can be attributed to homochiral chains of semithioglycoluril molecules (SI, Figure S4), held together

Table 3 Screening of Conditions for the Synthesis of DHI 5 I (Approach 2)

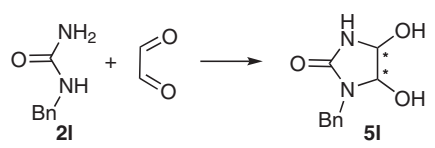

\begin{tabular}{|c|c|c|c|c|}
\hline Entry & Solvent & $\mathrm{pH}$ & Time (h) & Conv. $(\%)^{b}$ \\
\hline 1 & $\mathrm{MeOH}$ & 7 & 1 & 15 \\
\hline 2 & $\mathrm{MeOH}$ & 7 & 2 & 20 \\
\hline 3 & $\mathrm{MeOH}$ & 7 & 3 & 24 \\
\hline 4 & $\mathrm{MeOH}$ & 7 & 4 & 25 \\
\hline 5 & $i-\mathrm{PrOH}$ & 7 & 1 & 59 \\
\hline 6 & $i$-PrOH & 7 & 2 & 71 \\
\hline 7 & $i-\mathrm{PrOH}$ & 7 & 3 & 77 \\
\hline 8 & $i-\mathrm{PrOH}$ & 7 & 4 & 85 \\
\hline 9 & $i$-PrOH & 7 & 5 & $100^{c}$ \\
\hline 10 & $i-\mathrm{PrOH}$ & 10 & 3 & 33 \\
\hline
\end{tabular}

a Reaction conditions: 2 l ( $2 \mathrm{mmol})$, glyoxal hydrate trimer $(0.8 \mathrm{mmol})$, reflux.

${ }^{\mathrm{b}}$ Conversion of $\mathbf{2 l}$ into $\mathbf{5 l}$ according to ${ }^{1} \mathrm{H}$ NMR spectroscopy.

c Reaction conditions: $2 \mathbf{l}(0.30 \mathrm{~g}, 2 \mathrm{mmol})$, glyoxal hydrate trimer $(0.16 \mathrm{~g}$, $0.8 \mathrm{mmol}), i-\mathrm{PrOH}(5 \mathrm{~mL})$, reflux, $5 \mathrm{~h}$. 
by hydrogen bonds of the NH groups that are on the opposite side of the molecule from the above substituent ( $\mathrm{N}$... 2.820(3) $\AA$, NHO 178(1) and N...S 3.406(2) $\AA$, NHS 173(1) ${ }^{\circ}$ in 1a and N...O 2.765(5) $\AA$, NHO 176(1) ${ }^{\circ}$ and N...S 3.464(4) $\AA$, NHS $172(1)^{\circ}$ in $\mathbf{1 j}$ ). The third NH group links these homochiral chains (N...O 2.834(3) $\AA$, NHO $163(1)^{\circ}$ in 1a and $\mathrm{N} \ldots \mathrm{O}$ $3.018(5) \AA$, NHO $167(1)^{\circ}$ in $\mathbf{1 j}$ ), which are rotated to each other by ca. $90^{\circ}$ to result in a non-centrosymmetric hydrogen-bonded 3D framework. The $\mathrm{OH}$ group in $\mathbf{1} \mathbf{j}$ is involved in an intramolecular hydrogen bond with an adjacent oxygen atom $\mathrm{O}(1)\left(\mathrm{O} \cdots \mathrm{O} 2.614(5) \AA\right.$, OHO $\left.156(1)^{\circ}\right)$ and in a hydrogen bond with the third $\mathrm{NH}$ group from the molecule in a perpendicular chain, as the oxygen atom $\mathrm{O}(1)$ in $\mathbf{1 a}$ does (see above). In contrast, the semithioglycololurils $\mathbf{1 b}$ and $\mathbf{1 d}$ (SI, Figure S5) form centrosymmetric dimers through $\mathrm{N}-$ H...S hydrogen bonds (N...S 3.358(6) A, NHS $160(1)^{\circ}$ in 1b and N...S 3.569(3) Å, NHS $149(1)^{\circ}$ in 1d). They assemble chiral chains produced by an $\mathrm{N}-\mathrm{H}$... O hydrogen bond ( $\mathrm{N}$... $\mathrm{O}$ 2.874(8) $\AA$, NHO $177(1)^{\circ}$ in $\mathbf{1 b}$ and $\mathrm{N}$...O 2.885(4) $\AA$, NHO $144(1)^{\circ}$ in 1d) of the $\mathrm{NH}$ group that is on the same side of the molecule as the above substituents, into centrosymmetric sheets. Additionally stabilized by $\mathrm{N}-\mathrm{H}$...S hydrogen bonds formed the third NH group in $\mathbf{1 b}$ (N...S 3.464(6) $\AA$, NHS $\left.156(1)^{\circ}\right)$, those are held together by weak van der Waals interactions. In 1d, the same $\mathrm{NH}$ group is involved in an $\mathrm{N}-\mathrm{H}$...S hydrogen bond with the neighboring chiral chain $\left(\mathrm{N}\right.$... $3.564(3) \AA$, NHS $\left.137(1)^{\circ}\right)$, thus completing a centrosymmetric hydrogen-bonded 3D framework. As a result, the semithioglycolurils $\mathbf{1 b}$ and $\mathbf{1 d}$ were crystallized as racemates (SI, Table S1), and $\mathbf{1 a}$ and $\mathbf{1 j}$, as conglomerates. A possible explanation for this behavior is that the isopropyl and ethyl substituents are diverted towards the $\mathrm{NH}$ group in the former two compounds, somehow favoring the centrosymmetric arrangement of their molecules.

In summary, reactions of 1-substituted ureas with 4,5dihydroxy- or 4,5-dimethoxyimidazolidine-2-thione (approach 1) or with glyoxal, using the resulting 1-substituted 4,5-dihydroxyimidazolidine-2-ones, with NaSCN and hydrochloric acid in a two-step one-pot procedure (approach 2 ) were studied in detail by ${ }^{1} \mathrm{H}$ NMR spectroscopy. As a result of this comprehensive study, two new methods for the synthesis of 1-substituted semithioglycolurils were developed to provide 16 different products, 13 of which were reported for the first time. Two of these compounds produced the first conglomerates reported for semithioglycolurils, as unambiguously identified by X-ray diffraction. This research has made 1-substituted semithioglycolurils available, so that they can now be used in the synthesis of new heterocyclic compounds.

All reagents were purchased from commercial sources and used without further treatment, unless otherwise indicated. ${ }^{1} \mathrm{H}$ and ${ }^{13} \mathrm{C}$ NMR spectra were recorded at $25-29{ }^{\circ} \mathrm{C}$ with a Bruker AM300 and Bruker
DRX500 spectrometer and TMS as internal standard. HRMS (ESI) data were collected using a Bruker micrOTOF II mass spectrometer. 1Methyl- and 1-isopropyl-5-thioxohexahydroimidazo[4,5-d]imidazol$2(1 \mathrm{H})$-one $(\mathbf{1 a}, \mathbf{b})$ were synthesized earlier from 1-methyl- and 1-isopropylurea and 3 (DMIT).,25 1-Cyclohexyl-5-thioxohexahydroimidazo[4,5-d]imidazol-2 $(1 H)$-one (1c) was prepared earlier from 1-cyclohexyl-4,5-dihydroxyimidazolidine-2-one, $\mathrm{KSCN}$, and $\mathrm{HCl}^{14}$ 1-Alkylureas $\mathbf{2 b},{ }^{35} \mathbf{2 c},{ }^{36} \mathbf{2 e},{ }^{37} \mathbf{2 f},{ }^{35} \mathbf{2 h}^{38} \mathbf{2 i}^{39}{ }^{3 \mathbf{2}}{ }^{38}$ and $\mathbf{2} \mathbf{p}^{38}$ were synthesized by previously reported procedures from the corresponding amines, hydrochloric acid, and KOCN. 1-Phenethylurea $(\mathbf{2 n})^{40}$ was synthesized from 2-phenylethanamine, hydrochloric acid, and urea. 4,5-Dimethoxyimidazolidine-2-thione (3) was prepared from 4,5-dihydroxyimidazolidine-2-thione (4), $\mathrm{MeOH}$, and hydrochloric acid. ${ }^{32}$ 4,5-Dihydroxyimidazolidine-2-thione was synthesized by the condensation of thiourea with $40 \%$ aq glyoxal. ${ }^{41}$

\section{Thioglycolurils 1a-m,o,p; Approach 1}

4,5-Dihydroxyimidazolidine-2-thione $(4 ; 0.40 \mathrm{~g}, 3.0 \mathrm{mmol})$ and the appropriate urea $\mathbf{2 a}-\mathbf{m}, \mathbf{0}, \mathbf{p}(2.5 \mathrm{mmol})$ were suspended in $\mathrm{H}_{2} \mathrm{O}(10$ $\mathrm{mL})$. $\mathrm{Aq} \mathrm{HCl}(35 \%, 0.08 \mathrm{~mL})$ was added, and the solution was heated to $76-80{ }^{\circ} \mathrm{C}$ and stirred for $30 \mathrm{~min}$. The next day, the resulting precipitate was collected by filtration and air-dried (for $\mathbf{1 a - k , p ) . ~ T h e ~ r e s u l t - ~}$

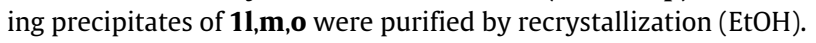

\section{Thioglycolurils 1a,b,d-h,j ; Approach 2}

A mixture of the appropriate 1-alkylurea $\mathbf{2 a}-\mathbf{e}, \mathbf{g}-\mathbf{j}$ (20 mmol), glyoxal hydrate trimer $(1.61 \mathrm{~g}, 7.7 \mathrm{mmol})$, and $\mathrm{H}_{2} \mathrm{O}(10 \mathrm{~mL})$ was heated to $50-$ $55^{\circ} \mathrm{C}$. Aq $\mathrm{NaOH}$ was added dropwise until $\mathrm{pH} 10$ was reached by the reaction mixture, which was then stirred for $3 \mathrm{~h}$. $\mathrm{MeOH}(20 \mathrm{~mL})$, $\operatorname{NaSCN}(3.65 \mathrm{~g}, 45 \mathrm{mmol})$, and $35 \%$ aq $\mathrm{HCl}(4.4 \mathrm{~mL})$ were added to the reaction mixture. The precipitate was removed by filtration and washed with $\mathrm{MeOH}(5 \mathrm{~mL})$. The filtrate was refluxed for $30 \mathrm{~min}$. Then the reaction mixture was cooled to r.t.

For $\mathbf{1 h}$ : The next day, the resulting precipitate of thioglycoluril $\mathbf{1 h}$ was collected by filtration, washed with $\mathrm{MeOH}$, and dried in air.

For $\mathbf{1 a , b , d - g : ~ T h e ~ r e a c t i o n ~ m i x t u r e ~ w a s ~ e v a p o r a t e d ~ t o ~ d r y n e s s , ~ a f t e r ~}$ which $\mathrm{CHCl}_{3}(10 \mathrm{~mL})$ was added under stirring. The precipitate was collected by filtration and washed with $\mathrm{H}_{2} \mathrm{O}(5 \mathrm{~mL})$.

For $\mathbf{1 j}$ : The reaction mixture of $\mathbf{1} \mathbf{j}$ was evaporated to dryness, and then the resulting mixture was dissolved in $\mathrm{H}_{2} \mathrm{O}(10 \mathrm{~mL})$ and $\mathrm{CHCl}_{3}(15$ $\mathrm{mL}$ ). The organic layer was collected and then evaporated to dryness. After the addition of $\mathrm{MeOH}(5 \mathrm{~mL})$, the precipitate was collected by filtration and air-dried.

\section{Thioglycolurils 1k-n; Approach 2}

A mixture of the appropriate 1-alkylurea $2 \mathbf{k}-\mathbf{n}(20 \mathrm{mmol})$, glyoxal hydrate trimer $(1.61 \mathrm{~g}, 7.7 \mathrm{mmol})$, and $i-\operatorname{PrOH}(10 \mathrm{~mL})$ was heated to reflux and stirred for $5 \mathrm{~h}$. MeOH (20 mL), NaSCN (3.65 g, $45 \mathrm{mmol}$ ), and $35 \%$ aq $\mathrm{HCl}(4.4 \mathrm{~mL})$ were added to the reaction mixture. The precipitate was removed by filtration and washed with $\mathrm{MeOH}(5 \mathrm{~mL})$. The filtrate was refluxed for $30 \mathrm{~min}$. Then the reaction mixture was cooled to r.t. The resulting precipitate was collected by filtration and air-dried.

1-Methyl-5-thioxohexahydroimidazo[4,5-d]imidazol-2(1H)-one $(1 \mathbf{a})^{6}$

Beige powder; yield: $0.22 \mathrm{~g}$ (51\%) (approach 1); brown crystals; yield: $1.07 \mathrm{~g}$ (31\%) (approach 2); mp 283-285 ${ }^{\circ} \mathrm{C}(\mathrm{MeOH})\left(283-285{ }^{\circ} \mathrm{C}\right.$ $\left.\left(\mathrm{H}_{2} \mathrm{O}\right)^{6}\right)$. 


\section{1-Isopropyl-5-thioxohexahydroimidazo[4,5-d]imidazol-2(1H)-} one $(\mathbf{1 b})^{25}$

Beige powder; yield: $0.25 \mathrm{~g}$ (50\%) (approach 1); brown crystals; yield: $2.08 \mathrm{~g} \mathrm{(52 \% )}$ (approach 2); $\mathrm{mp} 260-261{ }^{\circ} \mathrm{C}(\mathrm{MeOH})\left(260-261{ }^{\circ} \mathrm{C}\right.$ $\left.\left(\mathrm{H}_{2} \mathrm{O}\right)^{25}\right)$.

IR (KBr): 2975, 2894, 1677, 1533, 1492, 1337, 1225, 1210, 1105, 880, $755,634,586 \mathrm{~cm}^{-1}$.

${ }^{1} \mathrm{H}$ NMR (300 MHz, DMSO- $\left.d_{6}\right): \delta=0.61\left(\mathrm{~d},{ }^{3} \mathrm{~J}=6.6 \mathrm{~Hz}, 6 \mathrm{H}, \mathrm{Me}\right), 3.78-$ $3.92(\mathrm{~m}, 1 \mathrm{H}, \mathrm{CH}), 5.37\left(\mathrm{~d},{ }^{3} \mathrm{~J}=8.4 \mathrm{~Hz}, 1 \mathrm{H}, \mathrm{CH}\right), 5.52\left(\mathrm{~d},{ }^{3} \mathrm{~J}=8.5 \mathrm{~Hz}, 1 \mathrm{H}\right.$, $\mathrm{CH}), 7.42(\mathrm{~s}, 1 \mathrm{H}, \mathrm{NH}), 8.99$ (s, $1 \mathrm{H}, \mathrm{NH}), 9.04(\mathrm{~s}, 1 \mathrm{H}, \mathrm{NH})$.

${ }^{13} \mathrm{C}$ NMR (75 MHz, DMSO- $\left.d_{6}\right): \delta=18.98,21.42(\mathrm{Me}), 43.20(\mathrm{CH})$, 66.61, $69.87(\mathrm{CH}-\mathrm{CH}), 158.34(\mathrm{C}=\mathrm{O}), 182.80(\mathrm{C}=\mathrm{S})$.

HRMS (ESI): $m / z[\mathrm{M}+\mathrm{H}]^{+}$calcd for $\mathrm{C}_{7} \mathrm{H}_{12} \mathrm{~N}_{4} \mathrm{OS}+\mathrm{H}$ : 201.0805; found: 201.0805 .

\section{1-Cyclohexyl-5-thioxohexahydroimidazo[4,5-d]imidazol-2(1H)-} one (1c) $)^{14}$

Beige powder; yield: $0.39 \mathrm{~g}$ (65\%) (approach 1); mp 294-296 ${ }^{\circ} \mathrm{C}\left(\mathrm{H}_{2} \mathrm{O}\right)$ $\left(294-296{ }^{\circ} \mathrm{C}\left(\mathrm{H}_{2} \mathrm{O}\right)^{14}\right)$.

\section{1-Ethyl-5-thioxohexahydroimidazo[4,5-d]imidazol-2(1H)-one} (1d)

Beige powder; yield: $0.24 \mathrm{~g}$ (52\%) (approach 1); brown crystals; yield: $2.15 \mathrm{~g}$ (58\%) (approach 2); $\mathrm{mp} 256-258{ }^{\circ} \mathrm{C}(\mathrm{MeOH})$.

IR (KBr): 3348, 3185, 2980, 2877, 1680, 1527, 1489, 1341, 1309, 1251 , $1099,887,585 \mathrm{~cm}^{-1}$.

${ }^{1} \mathrm{H}$ NMR (300 MHz, DMSO- $d_{6}$ ): $\delta=1.02\left(\mathrm{t},{ }^{3} \mathrm{~J}=7.1 \mathrm{~Hz}, 3 \mathrm{H}, \mathrm{Me}\right), 3.01$ $\left(\mathrm{dq},{ }^{2} \mathrm{~J}=14.2 \mathrm{~Hz},{ }^{3} \mathrm{~J}=7.1 \mathrm{~Hz}, 1 \mathrm{H}, \mathrm{CH}_{2}\right), 3.26\left(\mathrm{dq},{ }^{2} \mathrm{~J}=14.4 \mathrm{~Hz},{ }^{3} \mathrm{~J}=7.2\right.$ $\left.\mathrm{Hz}, 1 \mathrm{H}, \mathrm{CH}_{2}\right), 5.37\left(\mathrm{~d},{ }^{3} \mathrm{~J}=8.4 \mathrm{~Hz}, 1 \mathrm{H}, \mathrm{CH}\right), 5.46\left(\mathrm{~d}, 3^{3}=8.4 \mathrm{~Hz}, 1 \mathrm{H}\right.$, $\mathrm{CH}), 7.49(\mathrm{~s}, 1 \mathrm{H}, \mathrm{NH}), 9.02(\mathrm{~s}, 1 \mathrm{H}, \mathrm{NH}), 9.15(\mathrm{~s}, 1 \mathrm{H}, \mathrm{NH})$.

${ }^{13} \mathrm{C}$ NMR (75 MHz, DMSO- $\left.d_{6}\right): \delta=12.83(\mathrm{Me}), 35.09\left(\mathrm{CH}_{2}\right), 66.31,71.1$ $(\mathrm{CH}-\mathrm{CH}), 158.46(\mathrm{C}=\mathrm{O}), 182.74(\mathrm{C}=\mathrm{S})$.

HRMS (ESI): $m / z[\mathrm{M}+\mathrm{Na}]^{+}$calcd for $\mathrm{C}_{6} \mathrm{H}_{10} \mathrm{~N}_{4} \mathrm{OS}+\mathrm{Na}$ : 209.0468; found: 209.0464 .

\section{1-Propyl-5-thioxohexahydroimidazo[4,5-d]imidazol-2(1H)-one \\ (1e)}

Beige powder; yield: $0.10 \mathrm{~g}$ (20\%) (approach 1), $2.20 \mathrm{~g}$ (55\%) (approach 2); mp $243-245^{\circ} \mathrm{C}(\mathrm{MeOH})$.

IR (KBr): 2967, 2932, 2879, 1682, 1531, 1492, 1250, 1206, 1100, 886 $\mathrm{cm}^{-1}$.

${ }^{1} \mathrm{H}$ NMR $\left(300 \mathrm{MHz}\right.$, DMSO- $\left.d_{6}\right): \delta=0.61\left(\mathrm{t},{ }^{3} \mathrm{~J}=7.3 \mathrm{~Hz}, 3 \mathrm{H}, \mathrm{Me}\right), 1.37-$ $1.57\left(\mathrm{~m}, 2 \mathrm{H}, \mathrm{CH}_{2}\right), 2.91-3.00\left(\mathrm{~m}, 1 \mathrm{H}, \mathrm{CH}_{2}\right), 3.08-3.33\left(\mathrm{~m}, 1 \mathrm{H}, \mathrm{CH}_{2}\right)$, $5.38\left(\mathrm{~d},{ }^{3} \mathrm{~J}=8.5 \mathrm{~Hz}, 1 \mathrm{H}, \mathrm{CH}\right), 5.44\left(\mathrm{~d},{ }^{3} \mathrm{~J}=8.5 \mathrm{~Hz}, 1 \mathrm{H}, \mathrm{CH}\right), 7.45(\mathrm{~s}, 1 \mathrm{H}$, $\mathrm{NH}), 8.98(\mathrm{~s}, 1 \mathrm{H}, \mathrm{NH}), 9.11(\mathrm{~s}, 1 \mathrm{H}, \mathrm{NH})$.

${ }^{13} \mathrm{C}$ NMR (75 MHz, DMSO- $\left.d_{6}\right): \delta=11.07(\mathrm{Me}), 20.31,41.91\left(\mathrm{CH}_{2}\right)$, 66.27, 71.45 (CH-CH), 158.66 ( $\mathrm{C}=\mathrm{O}), 182.71(\mathrm{C}=\mathrm{S})$.

HRMS (ESI): $m / z[\mathrm{M}+\mathrm{Na}]^{+}$calcd for $\mathrm{C}_{7} \mathrm{H}_{12} \mathrm{~N}_{4} \mathrm{OS}+\mathrm{Na}$ : 223.0624; found: 223.0627 .

\section{1-tert-Butyl-5-thioxohexahydroimidazo[4,5-d]imidazol-2(1H)-} one (1f)

Violet powder; yield: $0.33 \mathrm{~g}(61 \%)$ (approach 1); beige powder; yield: $2.61 \mathrm{~g}(50 \%)$ (approach 2$) ; \mathrm{mp} 278-280{ }^{\circ} \mathrm{C}\left(\mathrm{H}_{2} \mathrm{O}\right)$.

IR (KBr): 3182, 2974, 2900, 1687, 1535, 1487, 1254, 1214, 1158, 775, $744 \mathrm{~cm}^{-1}$.
${ }^{1} \mathrm{H}$ NMR (300 MHz, DMSO- $d_{6}$ ): $\delta=1.32\left(\mathrm{~s}, 9 \mathrm{H}, \mathrm{Me}\right.$ ), $5.25\left(\mathrm{~d},{ }^{3} \mathrm{~J}=8.3\right.$ $\mathrm{Hz}, 1 \mathrm{H}, \mathrm{CH}), 5.65$ (d, $\left.{ }^{3} \mathrm{~J}=8.3 \mathrm{~Hz}, 1 \mathrm{H}, \mathrm{CH}\right), 7.33$ (s, $\left.1 \mathrm{H}, \mathrm{NH}\right), 8.99$ (s, 2 $\mathrm{H}, \mathrm{NH})$.

${ }^{13} \mathrm{C}$ NMR (75 MHz, DMSO- $d_{6}$ ): $\delta=29.10$ (Me), $53.52(\mathrm{C}), 66.63,72.75$ $(\mathrm{CH}-\mathrm{CH}), 159.83(\mathrm{C}=\mathrm{O}), 184.09(\mathrm{C}=\mathrm{S})$.

HRMS (ESI): $m / z[\mathrm{M}+\mathrm{H}]^{+}$calcd for $\mathrm{C}_{8} \mathrm{H}_{14} \mathrm{~N}_{4} \mathrm{OS}+\mathrm{H}: 215.0961$; found: 215.0962 .

1-(Cyclopropylmethyl)-5-thioxohexahydroimidazo[4,5-d]imidazol-2(1H)-one (1g)

Beige powder; yield: $0.24 \mathrm{~g}$ (45\%) (approach 1), $2.25 \mathrm{~g}$ (53\%) (approach 2); $\mathrm{mp} 249-250{ }^{\circ} \mathrm{C}(\mathrm{MeOH})$.

IR (KBr): 3346, 3171, 3007, 2872, 1680, 1524, 1486, 1334, 1520, 1199 , $1097,1060,1020,886,724 \mathrm{~cm}^{-1}$.

${ }^{1} \mathrm{H}$ NMR $\left(300 \mathrm{MHz}\right.$, DMSO- $\left.d_{6}\right): \delta=0.08-0.14\left(\mathrm{~m}, 1 \mathrm{H}, \mathrm{CH}_{2}\right), 0.28-0.50$ $\left(\mathrm{m}, 3 \mathrm{H}, \mathrm{CH}_{2}\right), 0.83-0.96(\mathrm{~m}, 1 \mathrm{H}, \mathrm{CH}), 2.68\left(\mathrm{dd},{ }^{2} \mathrm{~J}=14.3 \mathrm{~Hz},{ }^{3} \mathrm{~J}=7.7 \mathrm{~Hz}\right.$, $\left.1 \mathrm{H}, \mathrm{CH}_{2}\right), 3.22\left(\mathrm{dd},{ }^{2} \mathrm{~J}=13.6 \mathrm{~Hz},{ }^{3} \mathrm{~J}=7.2 \mathrm{~Hz}, 1 \mathrm{H}, \mathrm{CH}_{2}\right), 5.41\left(\mathrm{~d},{ }^{3} \mathrm{~J}=8.4\right.$, $\mathrm{Hz}, 1 \mathrm{H}, \mathrm{CH}), 5.58\left(\mathrm{~d},{ }^{3} \mathrm{~J}=8.3, \mathrm{~Hz}, 1 \mathrm{H}, \mathrm{CH}\right), 7.51(\mathrm{~s}, 1 \mathrm{H}, \mathrm{NH}), 9.01(\mathrm{~s}, 1$ $\mathrm{H}, \mathrm{NH}), 9.15$ (s, $1 \mathrm{H}, \mathrm{NH})$.

${ }^{13} \mathrm{C}$ NMR $\left(75 \mathrm{MHz}\right.$, DMSO- $\left.d_{6}\right): \delta=3.29,3.96\left(\mathrm{CH}_{2}\right), 9.31(\mathrm{CH}), 44.62$ $\left(\mathrm{CH}_{2}\right), 66.37,71.39(\mathrm{CH}-\mathrm{CH}), 158.57(\mathrm{C}=\mathrm{O}), 182.79(\mathrm{C}=\mathrm{S})$.

HRMS (ESI): $m / z$ [M $+\mathrm{H}]^{+}$calcd for $\mathrm{C}_{8} \mathrm{H}_{12} \mathrm{~N}_{4} \mathrm{OS}+\mathrm{H}$ : 213.0810; found: 213.0807.

\section{1-(2-Hydroxyethyl)-5-thioxohexahydroimidazo[4,5-d]imidazol- 2(1H)-one (1h)}

Beige thin needles; yield: $0.13 \mathrm{~g}$ (26\%) (approach 1), $2.18 \mathrm{~g}$ (54\%) (approach 2); mp $250-252^{\circ} \mathrm{C}$ (MeOH).

IR (KBr): 3409, 3247, 2886, 2055, 1730, 1501, 1322, 1243, 1196, 1047 , $876,757 \mathrm{~cm}^{-1}$.

${ }^{1} \mathrm{H}$ NMR $\left(300 \mathrm{MHz}\right.$, DMSO- $\left.d_{6}\right): \delta=3.08\left(\mathrm{dt},{ }^{2} J=14.2 \mathrm{~Hz},{ }^{3} J=5.7 \mathrm{~Hz}, 1\right.$ $\left.\mathrm{H}, \mathrm{CH}_{2}\right), 3.24\left(\mathrm{dt},{ }^{2} \mathrm{~J}=14.1 \mathrm{~Hz},{ }^{3} \mathrm{~J}=6.1 \mathrm{~Hz}, 1 \mathrm{H}, \mathrm{CH}_{2}\right), 3.47\left(\mathrm{t},{ }^{3} \mathrm{~J}=5.9 \mathrm{~Hz}\right.$, $2 \mathrm{H}, \mathrm{CH}_{2}$ ), 4.45-5.11 (br. s, $1 \mathrm{H}, \mathrm{OH}$ ), 5.38 (d, ${ }^{3} \mathrm{~J}=8.4 \mathrm{~Hz}, 1 \mathrm{H}, \mathrm{CH}$ ), 5.49 $\left(\mathrm{d},{ }^{3} \mathrm{~J}=8.3 \mathrm{~Hz}, 1 \mathrm{H}, \mathrm{CH}\right), 7.53(\mathrm{~s}, 1 \mathrm{H}, \mathrm{NH}), 8.99(\mathrm{~s}, 1 \mathrm{H}, \mathrm{NH}), 9.04(\mathrm{~s}, 1 \mathrm{H}$, $\mathrm{NH})$.

${ }^{13} \mathrm{C}$ NMR $\left(75 \mathrm{MHz}\right.$, DMSO- $\left.d_{6}\right): \delta=42.94,58.68\left(\mathrm{CH}_{2}\right), 66.31,72.17$ ( $\mathrm{CH}-\mathrm{CH}), 158.75(\mathrm{C}=\mathrm{O}), 182.63(\mathrm{C}=\mathrm{S})$.

HRMS (ESI): $m / z[M+N a]^{+}$calcd for $\mathrm{C}_{6} \mathrm{H}_{10} \mathrm{~N}_{4} \mathrm{O}_{2} \mathrm{~S}+\mathrm{Na}$ : 225.0417; found: 225.0417 .

\section{1-(3-Hydroxypropyl)-5-thioxohexahydroimidazo[4,5-d]imidazol-} 2(1H)-one (1i)

Beige powder; yield: $0.08 \mathrm{~g}$ (15\%) (approach 1); mp 222-225 ${ }^{\circ} \mathrm{C}\left(\mathrm{H}_{2} \mathrm{O}\right)$. IR (KBr): 3421, 3317, 1680, 1528, 1494, 1249, 1203, 1094, 1058, 884 $\mathrm{cm}^{-1}$.

${ }^{1} \mathrm{H}$ NMR (300 MHz, DMSO- $d_{6}$ ): $\delta=1.55-1.68\left(\mathrm{~m}, 2 \mathrm{H}, \mathrm{CH}_{2}\right), 3.03(\mathrm{dt}$, $\left.{ }^{2} J=14.0 \mathrm{~Hz},{ }^{3} \mathrm{~J}=6.8 \mathrm{~Hz}, 1 \mathrm{H}, \mathrm{CH}_{2}\right), 3.26\left(\mathrm{dt},{ }^{2} \mathrm{~J}=14.0 \mathrm{~Hz},{ }^{3} \mathrm{~J}=7.0 \mathrm{~Hz}, 1 \mathrm{H}\right.$, $\left.\mathrm{CH}_{2}\right), 3.39\left(\mathrm{t},{ }^{3} \mathrm{~J}=6.2 \mathrm{~Hz}, 2 \mathrm{H}, \mathrm{CH}_{2}\right), 5.38\left(\mathrm{~d},{ }^{3} \mathrm{~J}=8.3 \mathrm{~Hz}, 1 \mathrm{H}, \mathrm{CH}\right), 5.44$ $\left(\mathrm{d},{ }^{3} \mathrm{~J}=8.4 \mathrm{~Hz}, 1 \mathrm{H}, \mathrm{CH}\right), 7.49(\mathrm{~s}, 1 \mathrm{H}, \mathrm{NH}), 9.01(\mathrm{~s}, 1 \mathrm{H}, \mathrm{NH}), 9.12(\mathrm{~s}, 1 \mathrm{H}$, $\mathrm{NH})$.

${ }^{13} \mathrm{C}$ NMR (75 MHz, DMSO- $\left.d_{6}\right): \delta=35.45,37.71,58.39\left(\mathrm{CH}_{2}\right), 66.29$, $71.62(\mathrm{CH}-\mathrm{CH}), 159.72(\mathrm{C}=\mathrm{O}), 182.72(\mathrm{C}=\mathrm{S})$.

HRMS (ESI): $m / z[\mathrm{M}+\mathrm{Na}]^{+}$calcd for $\mathrm{C}_{8} \mathrm{H}_{12} \mathrm{~N}_{4} \mathrm{O}_{2} \mathrm{~S}+\mathrm{Na}$ : 238.0573; found: 238.0567 . 
1-(1-Hydroxy-2-methylpropan-2-yl)-5-thioxohexahydroimidazo[4,5-d]imidazol-2(1H)-one (1j)

Beige powder; yield: $0.24 \mathrm{~g}$ (41\%) (approach 1), $2.07 \mathrm{~g}$ (45\%) (approach 2); mp $264-266{ }^{\circ} \mathrm{C}(\mathrm{MeOH})$.

IR (KBr): 3200, 2065, 1693, 1533, 1489, 1339, 1249, 1203, 1061, 888 $\mathrm{cm}^{-1}$.

${ }^{1} \mathrm{H}$ NMR (300 MHz, DMSO- $d_{6}$ ): $\delta=1.26$ (s, $6 \mathrm{H}, \mathrm{Me}$ ), 3.37 (d, ${ }^{2} J=10.9$ $\mathrm{Hz}, 1 \mathrm{H}, \mathrm{CH}_{2}$ ), $3.64\left(\mathrm{~d},{ }^{2} \mathrm{~J}=10.7 \mathrm{~Hz}, 1 \mathrm{H}, \mathrm{CH}_{2}\right), 4.77-5.14$ (br. s, $1 \mathrm{H}, \mathrm{OH}$ ), $5.28\left(\mathrm{~d},{ }^{3} \mathrm{~J}=8.4 \mathrm{~Hz}, 1 \mathrm{H}, \mathrm{CH}\right), 5.67\left(\mathrm{~d},{ }^{3} \mathrm{~J}=8.4 \mathrm{~Hz}, 1 \mathrm{H}, \mathrm{CH}\right), 7.38(\mathrm{~s}, 1 \mathrm{H}$, $\mathrm{NH}), 8.83(\mathrm{~s}, 1 \mathrm{H}, \mathrm{NH}), 9.00(\mathrm{~s}, 1 \mathrm{H}, \mathrm{NH})$.

${ }^{13} \mathrm{C}$ NMR (75 MHz, DMSO- $\left.d_{6}\right): \delta=24.21,24.29(\mathrm{Me}), 57.55\left(\mathrm{CH}_{2}\right)$, 66.92, 73.16 ( $\mathrm{CH}-\mathrm{CH}), 67.82\left(\mathrm{CMe}_{2}\right), 160.16(\mathrm{C}=\mathrm{O}), 183.93$ (C=S).

HRMS (ESI): $m / z$ [M + H] calcd for $\mathrm{C}_{8} \mathrm{H}_{14} \mathrm{~N}_{4} \mathrm{O}_{2} \mathrm{~S}+\mathrm{H}$ : 231.0910; found : 231.0905 .

\section{1-Allyl-5-thioxohexahydroimidazo[4,5-d]imidazol-2(1H)-one (1k)} Beige powder; yield: $0.20 \mathrm{~g}$ (40\%) (approach 1); white powder; yield: $2.45 \mathrm{~g}(62 \%)$ (approach 2$) ; \mathrm{mp} 245-247{ }^{\circ} \mathrm{C}(\mathrm{MeOH})$.

IR (KBr): 3200, 2879, 1719, 1529, 1490, 1340, 1294, 1245, 1201, 1115 , $1049,885,678 \mathrm{~cm}^{-1}$.

${ }^{1} \mathrm{H}$ NMR $\left(300 \mathrm{MHz}\right.$, DMSO- $\left.d_{6}\right): \delta=3.49\left(\mathrm{dd},{ }^{2} J=15.9 \mathrm{~Hz},{ }^{3} J=6.8 \mathrm{~Hz}, 1\right.$ $\left.\mathrm{H}, \mathrm{CH}_{2}\right), 3.92\left(\mathrm{dd},{ }^{2} \mathrm{~J}=15.5 \mathrm{~Hz},{ }^{3} \mathrm{~J}=3.7 \mathrm{~Hz}, 1 \mathrm{H}, \mathrm{CH}_{2}\right), 5.08-5.25(\mathrm{~m}, 2 \mathrm{H}$, $\left.\mathrm{CH}_{2}\right), 5.37\left(\mathrm{q},{ }^{3} \mathrm{~J}=8.3 \mathrm{~Hz}, 2 \mathrm{H}, \mathrm{CH}-\mathrm{CH}\right), 5.63-5.78(\mathrm{~m}, 1 \mathrm{H}, \mathrm{CH}), 7.6(\mathrm{~s}, 1$ $\mathrm{H}, \mathrm{NH}), 9.05$ (s, $1 \mathrm{H}, \mathrm{NH}), 9.17$ (s, $1 \mathrm{H}, \mathrm{NH})$.

${ }^{13} \mathrm{C}$ NMR $\left(75 \mathrm{MHz}\right.$, DMSO-d $\left.d_{6}\right): \delta=42.46\left(\mathrm{CH}_{2}\right), 66.32,71.02(\mathrm{CH}-\mathrm{CH})$, $117.49\left(\mathrm{CH}_{2}\right), 133.06(\mathrm{CH}), 158.31(\mathrm{C}=\mathrm{O}), 182.78(\mathrm{C}=\mathrm{S})$.

HRMS (ESI): $m / z[M+H]^{+}$calcd for $\mathrm{C}_{7} \mathrm{H}_{10} \mathrm{~N}_{4} \mathrm{OS}+\mathrm{H}$ : 199.0654; found: 199.0646

\section{1-Benzyl-5-thioxohexahydroimidazo[4,5-d]imidazol-2(1H)-one (11)}

Beige powder; yield: $0.27 \mathrm{~g}$ (45\%) (approach 1), $3.00 \mathrm{~g}$ (63\%) (approach 2); $\mathrm{mp} 259-261^{\circ} \mathrm{C}(\mathrm{MeOH})$.

IR (KBr): 3350, 3143, 3006, 2871, 1675, 1528, 1484, 1334, 1250, 1122 , $1081 \mathrm{~cm}^{-1}$.

${ }^{1} \mathrm{H}$ NMR $\left(300 \mathrm{MHz}\right.$, DMSO- $\left.d_{6}\right): \delta=4.01\left(\mathrm{~d},{ }^{2} J=15.5 \mathrm{~Hz}, 1 \mathrm{H}, \mathrm{CH}_{2}\right), 4.61$ $\left(\mathrm{d},{ }^{2} \mathrm{~J}=15.4 \mathrm{~Hz}, 1 \mathrm{H}, \mathrm{CH}_{2}\right), 5.22\left(\mathrm{~d},{ }^{3} \mathrm{~J}=8.3 \mathrm{~Hz}, 1 \mathrm{H}, \mathrm{CH}\right), 5.42\left(\mathrm{~d},{ }^{3} \mathrm{~J}=8.3\right.$ $\mathrm{Hz}, 1 \mathrm{H}, \mathrm{CH}), 7.27-7.39(\mathrm{~m}, 5 \mathrm{H}, \mathrm{Ph}), 7.72(\mathrm{~s}, 1 \mathrm{H}, \mathrm{NH}), 9.12(\mathrm{~s}, 1 \mathrm{H}, \mathrm{NH})$, $9.31(\mathrm{~s}, 1 \mathrm{H}, \mathrm{NH})$.

${ }^{13} \mathrm{C}$ NMR (75 MHz, DMSO- $\left.d_{6}\right): \delta=43.31\left(\mathrm{CH}_{2}\right), 66.33,70.77(\mathrm{CH}-\mathrm{CH})$, 127.25, 127.82, $128.49(\mathrm{CH}(\mathrm{Ph})), 137.25(\mathrm{C}(\mathrm{Ph})), 158.48(\mathrm{C}=\mathrm{O}), 182.83$ $(\mathrm{C}=\mathrm{S})$.

HRMS (ESI): $m / z[\mathrm{M}+\mathrm{Na}]^{+}$calcd for $\mathrm{C}_{11} \mathrm{H}_{12} \mathrm{~N}_{4} \mathrm{OS}+\mathrm{Na}: 271.0624$; found: 271.0625 .

\section{1-(4-Methoxybenzyl)-5-thioxohexahydroimidazo[4,5-d]imidazol- 2(1H)-one (1m)}

Beige powder; yield: $0.32 \mathrm{~g}$ (46\%) (approach 1), $3.61 \mathrm{~g}$ (65\%) (approach 2$)$; mp $264-265^{\circ} \mathrm{C}(\mathrm{MeOH})$.

IR (KBr): 3348, 3133, 3003, 2871, 1673, 1518, 1483, 1334, 1246, 1178 , $1101,1023 \mathrm{~cm}^{-1}$.

${ }^{1} \mathrm{H}$ NMR (300 MHz, DMSO- $d_{6}$ ): $\delta=3.76$ (s, $3 \mathrm{H}, \mathrm{Me}$ ), 3.91 (d, ${ }^{2} J=15.1$ $\left.\mathrm{Hz}, 1 \mathrm{H}, \mathrm{CH}_{2}\right), 4.56\left(\mathrm{~d},{ }^{2} J=15.1 \mathrm{~Hz}, 1 \mathrm{H}, \mathrm{CH}_{2}\right), 5.17\left(\mathrm{~d},{ }^{3} J=8.4 \mathrm{~Hz}, 1 \mathrm{H}\right.$, $\mathrm{CH}), 5.39\left(\mathrm{~d},{ }^{3} \mathrm{~J}=8.4 \mathrm{~Hz}, 1 \mathrm{H}, \mathrm{CH}\right), 6.91\left(\mathrm{~d},{ }^{3} \mathrm{~J}=8.5 \mathrm{~Hz}, 2 \mathrm{H}, \mathrm{CH}(\mathrm{PMB})\right.$ ), 7.23 (d, $\left.{ }^{3} \mathrm{~J}=8.5 \mathrm{~Hz}, 2 \mathrm{H}, \mathrm{CH}(\mathrm{PMB})\right), 7.07$ (s, $\left.1 \mathrm{H}, \mathrm{NH}\right), 9.10(\mathrm{~s}, 1 \mathrm{H}, \mathrm{NH})$, $9.31(\mathrm{~s}, 1 \mathrm{H}, \mathrm{NH})$.
${ }^{13} \mathrm{C}$ NMR (75 MHz, DMSO- $\left.d_{6}\right): \delta=42.70\left(\mathrm{CH}_{2}\right), 55.11$ (OMe), 66.30, 70.55 (CH-CH), 113.95, 129.40, 128.49 (CH(PMB)), 119.04 (C(PMB)), 158.44, $158.62(\mathrm{C}=\mathrm{O}+\mathrm{C}-\mathrm{OMe}), 182.83(\mathrm{C}=\mathrm{S})$.

HRMS (ESI): $m / z[\mathrm{M}+\mathrm{H}]^{+}$calcd for $\mathrm{C}_{12} \mathrm{H}_{14} \mathrm{~N}_{4} \mathrm{O}_{2} \mathrm{~S}+\mathrm{H}$ : 279.0910; found: 279.0912 .

\section{1-Phenethyl-5-thioxohexahydroimidazo[4,5-d]imidazol-2(1H)-} one (1n)

Beige powder; yield: $3.20 \mathrm{~g}$ (61\%) (approach 2); $\mathrm{mp} 259-260{ }^{\circ} \mathrm{C}$ $(\mathrm{MeOH})$.

IR (KBr): 3331, 3164, 1677, 1527, 1487, 1340, 1252, 1024, 1123, 1096 , $885,751,702,580 \mathrm{~cm}^{-1}$.

${ }^{1} \mathrm{H}$ NMR $\left(300 \mathrm{MHz}\right.$, DMSO- $\left.d_{6}\right): \delta=2.69-2.90\left(\mathrm{~m}, 2 \mathrm{H}, \mathrm{CH}_{2}\right), 3.19-3.48$ $\left(\mathrm{m}, 2 \mathrm{H}, \mathrm{CH}_{2}\right), 5.38\left(\mathrm{~d},{ }^{3} \mathrm{~J}=8.4 \mathrm{~Hz}, 1 \mathrm{H}, \mathrm{CH}\right), 5.47\left(\mathrm{~d},{ }^{3} \mathrm{~J}=8.3 \mathrm{~Hz}, 1 \mathrm{H}\right.$, $\mathrm{CH}), 7.18-7.33$ (m, $5 \mathrm{H}, \mathrm{Ph}), 7.44(\mathrm{~s}, 1 \mathrm{H}, \mathrm{NH}), 8.92(\mathrm{~s}, 1 \mathrm{H}, \mathrm{NH}), 9.20$ (s, $1 \mathrm{H}, \mathrm{NH})$.

${ }^{13} \mathrm{C}$ NMR (75 MHz, DMSO- $\left.d_{6}\right): \delta=23.38,41.96\left(\mathrm{CH}_{2}\right), 66.36,71.55$ (CH-CH), 126.19, 128.36, $128.71(\mathrm{CH}(\mathrm{Ph})), 139.03(\mathrm{C}(\mathrm{Ph})), 158.52$ $(\mathrm{C}=0), 182.70(\mathrm{C}=\mathrm{S})$.

HRMS (ESI): $m / z[M+N a]^{+}$calcd for $\mathrm{C}_{12} \mathrm{H}_{14} \mathrm{~N}_{4} \mathrm{OS}+\mathrm{Na}$ : 285.0781; found: 285.0777 .

\section{1-Phenyl-5-thioxohexahydroimidazo[4,5-d]imidazol-2(1H)-one} (10)

Violet powder; yield: $0.20 \mathrm{~g}$ (34\%) (approach 1); $\mathrm{mp}>300{ }^{\circ} \mathrm{C}(\mathrm{MeOH})$. IR (KBr): 3345, 3177, 1689, 1529, 1503, 1422, 1328, 1266, 1142, 1102 , $887,748,691 \mathrm{~cm}^{-1}$.

${ }^{1} \mathrm{H}$ NMR (300 MHz, DMSO- $d_{6}$ ): $\delta=5.54\left(\mathrm{~d},{ }^{3} J=8.4 \mathrm{~Hz}, 1 \mathrm{H}, \mathrm{CH}\right), 6.09$ $\left(\mathrm{d},{ }^{3} \mathrm{~J}=8.5 \mathrm{~Hz}, 1 \mathrm{H}, \mathrm{CH}\right), 7.08\left(\mathrm{t},{ }^{3} \mathrm{~J}=7.3 \mathrm{~Hz}, 1 \mathrm{H}, \mathrm{Ph}\right), 7.33\left(\mathrm{t},{ }^{3} \mathrm{~J}=7.8 \mathrm{~Hz}\right.$, $2 \mathrm{H}, \mathrm{Ph}), 7.56$ (d, $\left.{ }^{3} \mathrm{~J}=8.1 \mathrm{~Hz}, 2 \mathrm{H}, \mathrm{Ph}\right), 8.18(\mathrm{~s}, 1 \mathrm{H}, \mathrm{NH}), 9.29$ (d, $1 \mathrm{H}$, $\mathrm{NH}), 9.42$ (s, $1 \mathrm{H}, \mathrm{NH})$.

${ }^{13} \mathrm{C}$ NMR (75 MHz, DMSO- $\left.d_{6}\right): \delta=65.77,71.79(\mathrm{CH}-\mathrm{CH}), 119.10$, 123.06, $128.63(\mathrm{CH}(\mathrm{Ph})), 138.01(\mathrm{C}(\mathrm{Ph})), 156.35(\mathrm{C}=\mathrm{O}), 183.47(\mathrm{C}=\mathrm{S})$.

HRMS (ESI): $m / z[\mathrm{M}+\mathrm{Na}]^{+}$calcd for $\mathrm{C}_{10} \mathrm{H}_{10} \mathrm{~N}_{4} \mathrm{OS}+\mathrm{Na}$ : 257.0468; found: 257.0465 .

\section{4-[2-0xo-5-thioxohexahydroimidazo[4,5-d]imidazol-1(2H)-yl]- butanoic Acid (1p)}

Beige powder; yield: $0.22 \mathrm{~g}$ (36\%) (approach 1); mp $215-216^{\circ} \mathrm{C}\left(\mathrm{H}_{2} \mathrm{O}\right)$. IR (KBr): 3405, 3331, 3181, 1715, 1651, 1500, 1337, 1243, 1205, 1129, $1083,933,887,812 \mathrm{~cm}^{-1}$.

${ }^{1} \mathrm{H}$ NMR (300 MHz, DMSO- $\left.d_{6}\right): \delta=1.60-1.80\left(\mathrm{~m}, 2 \mathrm{H}, \mathrm{CH}_{2}\right), 2.16(\mathrm{t}$, $\left.{ }^{3} J=7.5 \mathrm{~Hz}, 2 \mathrm{H}, \mathrm{CH}_{2}\right), 3.00\left(\mathrm{dt},{ }^{2} J=13.9 \mathrm{~Hz},{ }^{3} \mathrm{~J}=6.8 \mathrm{~Hz}, 1 \mathrm{H}, \mathrm{CH}_{2}\right), 3.19$ $\left(\mathrm{dt},{ }^{2} \mathrm{~J}=14.0 \mathrm{~Hz},{ }^{3} \mathrm{~J}=7.6 \mathrm{~Hz}, 1 \mathrm{H}, \mathrm{CH}_{2}\right), 5.37\left(\mathrm{~d},{ }^{3} \mathrm{~J}=8.4 \mathrm{~Hz}, 1 \mathrm{H}, \mathrm{CH}\right.$ ), $5.44\left(\mathrm{~d},{ }^{3} \mathrm{~J}=8.4 \mathrm{~Hz}, 1 \mathrm{H}, \mathrm{CH}\right), 7.53(\mathrm{~s}, 1 \mathrm{H}, \mathrm{NH}), 9.04(\mathrm{~s}, 1 \mathrm{H}, \mathrm{NH}), 9.14(\mathrm{~s}$, $1 \mathrm{H}, \mathrm{NH}), 11.81-12.32$ (br s, $1 \mathrm{H}, \mathrm{COOH}$ ).

${ }^{13} \mathrm{C}$ NMR (75 MHz, DMSO- $\left.d_{6}\right): \delta=22.64,31.01,39.78\left(\mathrm{CH}_{2}\right), 66.34$, $71.44(\mathrm{CH}-\mathrm{CH}), 158.72(\mathrm{C}=\mathrm{O}), 174.05(\mathrm{COOH}), 182.74(\mathrm{C}=\mathrm{S})$.

HRMS (ESI): $m / z[\mathrm{M}+\mathrm{Na}]^{+}$calcd for $\mathrm{C}_{8} \mathrm{H}_{12} \mathrm{~N}_{4} \mathrm{O}_{2} \mathrm{~S}+\mathrm{Na}: 267.0522$; found: 267.0524 .

\section{1-(4-Methoxybenzyl)urea (2m)}

Urea (200 mmol, $12.00 \mathrm{~g}$ ) was dissolved in $\mathrm{H}_{2} \mathrm{O}(50 \mathrm{~mL})$; then, (4-methoxyphenyl)methanamine $(5.2 \mathrm{~mL}, 40 \mathrm{mmol})$ and $35 \%$ aq $\mathrm{HCl}(2.5$ $\mathrm{mL}$ ) were added. The reaction mixture was refluxed for $4 \mathrm{~h}$ and then cooled to r.t. The resulting precipitate was collected by filtration, washed with $\mathrm{H}_{2} \mathrm{O}(50 \mathrm{~mL})$, and dried in air. 
White crystalline plates; yield: $3.82 \mathrm{~g} \mathrm{(53 \% );} \mathrm{mp} 159-160{ }^{\circ} \mathrm{C}\left(\mathrm{H}_{2} \mathrm{O}\right)$ $\left(158-159^{\circ} \mathrm{C}^{42}\right)$.

\section{Ureas 2d,g}

The corresponding amine ( $38 \mathrm{mmol})$ was dissolved in $\mathrm{H}_{2} \mathrm{O}(40 \mathrm{~mL})$, and then $35 \%$ aq $\mathrm{HCl}(2.1 \mathrm{~mL})$ was added dropwise. The reaction mixture was heated to reflux, and then KOCN (40 mmol, $3.24 \mathrm{~g}$ ) was added portionwise. The reaction mixture was refluxed for $30 \mathrm{~min}$ and then cooled to r.t. The resulting precipitate was collected by filtration and recrystallized from EtOH.

\section{1-Propylurea (2d)}

White powder; yield: $3.45 \mathrm{~g}(89 \%)$; $\mathrm{mp} 109-110{ }^{\circ} \mathrm{C}\left(173-174{ }^{\circ} \mathrm{C}^{43}\right)$.

\section{1-(Cyclopropylmethyl)urea (2g)}

Beige powder; yield: $3.81 \mathrm{~g}(88 \%)$; mp $122-124{ }^{\circ} \mathrm{C}(\mathrm{MeOH})$.

IR (KBr): 3416, 3217, 1657, 1605, 1547, 1359, 1310, 1145, $559 \mathrm{~cm}^{-1}$.

${ }^{1} \mathrm{H}$ NMR $\left(300 \mathrm{MHz}\right.$, DMSO- $\left.d_{6}\right): \delta=0.03-0.15\left(\mathrm{~m}, 2 \mathrm{H}, \mathrm{CH}_{2}\right), 0.29-0.42$ ( $\left.\mathrm{m}, 2 \mathrm{H}, \mathrm{CH}_{2}\right), 0,76-0.92(\mathrm{~m}, 1 \mathrm{H}, \mathrm{CH}), 2.83\left(\mathrm{t}, 3^{3}=6.1 \mathrm{~Hz}, 2 \mathrm{H}, \mathrm{CH}_{2}\right)$, $5.39\left(\mathrm{~s}, 2 \mathrm{H}, \mathrm{NH}_{2}\right), 5.97(\mathrm{~s}, 1 \mathrm{H}, \mathrm{NH})$.

${ }^{13} \mathrm{C}$ NMR $\left(75 \mathrm{MHz}\right.$, DMSO- $\left.d_{6}\right): \delta=2.97\left(\mathrm{CH}_{2}\right), 11.47(\mathrm{CH}), 43.50\left(\mathrm{CH}_{2}\right)$, $158.71(\mathrm{C}=0)$.

HRMS (ESI): $m / z$ [M $+\mathrm{H}]^{+}$calcd for $\mathrm{C}_{5} \mathrm{H}_{10} \mathrm{~N}_{2} \mathrm{O}+\mathrm{H}: 115.0871$; found: 115.0863

\section{$\left(8 S^{*}, 8 a S^{*}\right)-8$-Methoxytetrahydro-2H-imidazo[5,1-b][1,3]oxazine- 6(7H)-one (6)}

A mixture of $2 \mathbf{i}(0.24 \mathrm{~g}, 20 \mathrm{mmol})$, glyoxal hydrate trimer $(1.61 \mathrm{~g}, 7.7$ $\mathrm{mmol})$, and $\mathrm{H}_{2} \mathrm{O}(10 \mathrm{~mL})$ was heated to $50-55^{\circ} \mathrm{C}$. Then $\mathrm{NaOH}\left(\mathrm{H}_{2} \mathrm{O}\right)$ was added dropwise until pH 10 was achieved by the reaction mixture, which was then stirred for $3 \mathrm{~h}$. MeOH (20 mL), NaSCN (3.65 g, 45 $\mathrm{mmol})$, and $35 \%$ aq $\mathrm{HCl}(4.4 \mathrm{~mL})$ were added to the reaction mixture. The precipitate was removed by filtration and washed with $\mathrm{MeOH}(5$ $\mathrm{mL}$ ). The filtrate was refluxed for $30 \mathrm{~min}$. Then the reaction mixture was cooled to r.t. The reaction mixture was evaporated to dryness, then acetone $(5 \mathrm{~mL})$ was added, and the resulting precipitate of compound 6 was collected by filtration and air-dried.

White powder; yield: $0.31 \mathrm{~g}(9 \%) ; \mathrm{mp} 164-166^{\circ} \mathrm{C}$ (acetone).

IR (KBr): 3207, 3114, 2920, 1707, 1478, 1434, 1353, 1253, 1080, 953, $780,679 \mathrm{~cm}^{-1}$.

${ }^{1} \mathrm{H}$ NMR $\left(300 \mathrm{MHz}\right.$, DMSO- $\left.d_{6}\right): \delta=1.31-1.41\left(\mathrm{~m}, 1 \mathrm{H}, \mathrm{CH}_{2}\right), 1.44-1.62$ ( $\left.\mathrm{m}, 1 \mathrm{H}, \mathrm{CH}_{2}\right), 2.96-3.10\left(\mathrm{~m}, 1 \mathrm{H}, \mathrm{CH}_{2}\right), 3.20(\mathrm{~s}, 3 \mathrm{H}, \mathrm{Me}), 3.64-3.77(\mathrm{~m}$, $\left.2 \mathrm{H}, \mathrm{CH}_{2}\right), 3.89-3.98\left(\mathrm{~m}, 1 \mathrm{H}, \mathrm{CH}_{2}\right), 4.44(\mathrm{~s}, 1 \mathrm{H}, \mathrm{CH}), 4.79(\mathrm{~s}, 1 \mathrm{H}, \mathrm{CH})$, $8.02(\mathrm{~s}, 1 \mathrm{H}, \mathrm{NH})$.

${ }^{13} \mathrm{C}$ NMR $\left(75 \mathrm{MHz}\right.$, DMSO- $\left.d_{6}\right): \delta=24.62,37.48,65.26\left(\mathrm{CH}_{2}\right), 53.38$ (Me), 85.67, $87.58(\mathrm{CH}-\mathrm{CH}), 159.03(\mathrm{C}=0)$.

HRMS (ESI): $m / z[\mathrm{M}+\mathrm{Na}]^{+}$calcd for $\mathrm{C}_{7} \mathrm{H}_{12} \mathrm{~N}_{2} \mathrm{O}_{3}+\mathrm{Na}$ : 195.0740 ; found: 195.0737.

\section{X-ray Diffraction}

X-ray diffraction data for $\mathbf{1} \mathbf{a}, \mathbf{b}, \mathbf{d}, \mathbf{j}$ were collected at $120 \mathrm{~K}$ on a Bruker APEX2 DUO CCD diffractometer, using graphite monochromated MoK $\alpha$ radiation $(\lambda=0.71073 \AA)$. Using Olex $2,{ }^{44}$ the structures were solved with the ShelXT ${ }^{45}$ structure solution program using intrinsic phasing and refined against $F^{2}$ in the anisotropic-isotropic approximation with the olex2.refine ${ }^{46}$ refinement package using leastsquares minimization. The hydrogen atoms of $\mathrm{NH}$ and $\mathrm{OH}$ groups were found in the difference Fourier synthesis, the positions of other hydrogen atoms were calculated, and they all were refined in the isotropic approximation within the riding model. Crystal data and structure refinement parameters are given in Table S1 (SI). CCDC 1992118, 1992119, 1992120, and 1992121 (1a, 1b, 1d, and $\mathbf{1 j}$, respectively) contain the supplementary crystallographic data for this paper. These data can be obtained free of charge from The Cambridge Crystallographic Data Centre via www.ccdc.cam.ac.uk/getstructures.

\section{Funding Information}

The Scientific Schools Development Program by the Zelinsky Institute of Organic Chemistry is gratefully acknowledged.

\section{Acknowledgment}

X-ray diffraction data were collected using the equipment of the Center for Molecular Composition Studies of the A. N. Nesmeyanov Institute of Organoelement Compounds of the Russian Academy of Sciences (INEOS RAS).

\section{Supporting Information}

Supporting information for this article is available online at https://doi.org/10.1055/s-0040-1707391.

\section{References}

(1) Schiff, H. Liebigs Ann. Chem. 1877, 189, 157.

(2) Kravchenko, A. N.; Baranov, V. V.; Gazieva, G. A. Russ. Chem. Rev. 2018, 87, 89.

(3) Anikina, L. V.; Vikharev, Yu. B.; Baranov, V. V.; Malyshev, O. R.; Kravchenko, A. N. Mendeleev Commun. 2018, 28, 317.

(4) Baranov, V. V.; Antonova, M. M.; Kolotyrkina, N. G.; Zanin, I. E.; Kravchenko, A. N. Synlett 2019, 30, 299.

(5) Baranov, V. V.; Baganova, A. A.; Chikunov, I. E.; Karnoukhova, V. A.; Kravchenko, A. N. Tetrahedron Lett. 2019, 60, 1174.

(6) Baranov, V. V.; Yatsenko, E. L.; Melnikova, E. K.; Nelyubina, Y. V.; Kravchenko, A. N. Chem. Heterocycl. Compd. 2019, 55, 160.

(7) Saloutina, L. V.; Zapevalov, A. Ya.; Kodes, M. I.; Gamebnikh, I. N.; Saloutin, V. I.; Chupakhin, O. N. J. Fluorine Chem. 2018, 212, 144.

(8) Verner, J.; Taraba, J.; Potáček, M. Tetrahedron Lett. 2002, 43, 4833.

(9) Verner, J.; Potáček, M. Cent. Eur. J. Chem. 2004, 2, 220.

(10) Cow, C. N.; Harrison, P. H. M. J. Org. Chem. 1997, 62, 8834.

(11) Singh, M.; Solel, E.; Keinan, E.; Reany, O. Chem. Eur. J. 2015, 21, 536.

(12) Gazieva, G. A.; Anikina, L. V.; Nechaeva, T. V.; Pukhov, S. A.; Karpova, T. B.; Popkov, S. V.; Nelyubina, Yu. V.; Kolotyrkina, N. G.; Kravchenko, A. N. Eur. J. Med. Chem. 2017, 140, 141.

(13) Gazieva, G. A.; Anikina, L. V.; Pukhov, S. A.; Karpova, T. B.; Nelyubina, Yu. V.; Kravchenko, A. N. Mol. Diversity 2016, $20,837$.

(14) Baranov, V. V.; Nelyubina, Y. V.; Kravchenko, A. N.; Kolotyrkina, N. G.; Biriukova, K. A. Tetrahedron Lett. 2015, 56, 6085.

(15) Gazieva, G. A.; Baranov, V. V.; Kravchenko, A. N.; Makhova, N. N. Russ. J. Org. Chem. 2011, 47, 1572.

(16) Gazieva, G. A.; Lozhkin, P. V.; Baranov, V. V.; Nelyubina, Yu. V.; Kravchenko, A. N.; Makhova, N. N. Russ. Chem. Bull. 2009, 58, 2488. 
(17) Gazieva, G. A.; Vasilevskii, S. V.; Belyakov, P. A.; Nelyubina, Yu. V.; Lubuzh, E. D.; Kravchenko, A. N. Mendeleev Commun. 2010, 5, 285.

(18) Gazieva, G. A.; Poluboyarov, P. A.; Popov, L. D.; Kolotyrkina, N. G.; Kravchenko, A. N.; Makhova, N. N. Synthesis 2012, 44, 3366.

(19) Gazieva, G. A.; Vikharev, Y. B.; Anikina, L. V.; Karpova, T. B.; Kravchenko, A. N.; Permyakov, E. A.; Svitanko, I. V. Mendeleev Commun. 2013, 23, 202.

(20) Gazieva, G. A.; Kravchenko, A. N. J. Heterocycl. Chem. 2015, 52, 1858.

(21) Gazieva, G. A.; Karpova, T. B.; Popov, L. D.; Nelyubina, Yu. V.; Kravchenko, A. N. J. Heterocycl. Chem. 2015, 52, 1390.

(22) Gazieva, G. A.; Karpova, T. B.; Nechaeva, T. V.; Nelyubina, Y. V.; Zanin, I. E.; Kravchenko, A. N. Synlett 2017, 28, 858.

(23) Gazieva, G. A.; Nechaeva, T. V.; Kostikova, N. N.; Sigay, N. V.; Serkov, S. A.; Popkov, S. V. Russ. Chem. Bull. 2018, 67, 1059.

(24) Kravchenko, A. N.; Gazieva, G. A.; Vasilevskii, S. V.; Belyakov, P. A.; Nelyubina, Y. V. Mendeleev Commun. 2012, 6, 299.

(25) Eres'ko, V. A.; Epishina, L. V.; Lebedev, O. V.; Povstyanoi, M. V.; Khmel'nitskii, L. I.; Novikov, S. S. Bull. Acad. Sci. USSR, Div. Chem. Sci. 1980, 29, 1138.

(26) Baranov, V. V.; Gazieva, G. A.; Nelyubina, Y. V.; Kravchenko, A. N.; Makhova, N. N. Russ. J. Org. Chem. 2011, 47, 1564.

(27) Mondal, P.; Solel, E.; Mitra, S.; Keinan, E.; Reany, O. Org. Lett. 2020, 22, 204.

(28) Mock, W. L.; Manimaran, T.; Freeman, W. A.; Kuksuk, R. M.; Maggio, J. E.; Williams, D. H. J. Org. Chem. 1985, 50, 60.

(29) Barsegyan, Y. A.; Baranov, V. V.; Kravchenko, A. N. Chem. Heterocycl. Compd. 2017, 53, 116.

(30) Barsegyan, Y. A.; Baranov, V. V.; Kravchenko, A. N.; Strelenko, Y. A.; Anikina, L. V.; Karnoukhova, V. A.; Kolotyrkina, N. G. Synthesis 2018, 50, 2099.
(31) Baranov, V. V.; Barsegyan, Ya. A.; Kolotyrkina, N. G.; Kravchenko, A. N. Mendeleev Commun. 2019, 29, 323.

(32) Gazieva, G. A.; Nelyubina, Yu. V.; Kravchenko, A. N.; Sigachev, A. S.; Glukhov, I. V.; Struchkova, M. I.; Lyssenko, K. A.; Makhova, N. N. Russ. Chem. Bull. 2012, 58, 1945.

(33) Kravchenko, A. N.; Baranov, V. V.; Nelyubina, Yu. V.; Gazieva, G. A.; Svitan'ko, I. V. Russ. Chem. Bull. 2012, 61, 64.

(34) Vail, S. L.; Barker, B. H.; Menitt, P. G. J. Org. Chem. 1965, 30, 2179.

(35) Tiwari, T.; Kumar, V.; Kumar, B.; Mahajan, D. RSC Adv. 2018, 8 , 21585.

(36) Kravchenko, A. N.; Chikunov, I. E.; Gazieva, G. A.; Makhova, N. N. Mendeleev Commun. 2016, 26, 136.

(37) Wu, F.; Alom, N. E.; Ariyarathna, J. P.; Naß, J.; Li, W. Angew. Chem. Int. Ed. 2019, 58, 11676.

(38) Kravchenko, A. N.; Maksareva, E. Yu.; Belyakov, P. A.; Sigachev, A. S.; Chegaev, K. Yu.; Lyssenko, K. A.; Lebedev, O. V.; Makhova, N. N. Russ. Chem. Bull. 2003, 52, 192.

(39) Antonova, M. M.; Baranov, V. V.; Nelyubina, Yu. V.; Kravchenko, A. N. Chem. Heterocycl. Compd. 2014, 50, 503.

(40) Nagarkar, A. G.; Telvekar, V. N. Lett. Org. Chem. 2018, 15, 926.

(41) Nelyubina, Yu. V.; Gazieva, G. A.; Baranov, V. V.; Belyakov, P. A.; Chizhov, A. O.; Lyssenko, K. A.; Kravchenko, A. N. Russ. Chem. Bull. 2009, 58, 1353.

(42) Häcker, H. G.; Meusel, M.; Aschfalk, M.; Gütschow, M. ACS Comb. Sci. 2011, 13, 59.

(43) Boivin, J. L.; Boivin, P. A. Can. J. Chem. 1951, 29, 478.

(44) Dolomanov, O. V.; Bourhis, L. J.; Gildea, R. J.; Howard, J. A. K.; Puschmann, H. J. Appl. Crystallogr. 2009, 42, 339.

(45) Sheldrick, G. M. Acta Crystallogr., Sect. A 2015, 71, 3.

(46) Bourhis, L. J.; Dolomanov, O. V.; Gildea, R. J.; Howard, J. A. K.; Puschmann, H. Acta Crystallogr., Sect. A 2015, 71, 59. 